\title{
NEW SOURCES OF EFFECTIVE RESISTANCE GENES TO FUSARIUM WILT IN FLAX (Linum usitatissimum L.) DEPENDING ON TEMPERATURE
}

\section{T.A. ROZHMINA, N.I. LOSHAKOVA}

All-Russian Flax Research Institute, Federal Agency of Scientific Organizations, 35, ul. Lunacharskogo, Torzhok, Tver' Province, 172002 Russia, e-mail vniil@mail.ru

Received March 19, 2015

\begin{abstract}
Fusarium wilt caused mainly by fungus Fusarium oxysporum f. lini, is one of the most harmful and widespread diseases in flax. To increase the efficiency of breeding fiber and oil flax plants resistant to the pathogen, the sufficient set of the parent plants possessing effective R-genes is necessary. Development of monogene-based resistant varieties will allow to reduce the time required for breeding, and provide essential suppression of disease. In the present research we tested the resistance of world Linum usitatissimum L. gene pool specimens to highly aggressive Fusarium oxysporum f. lini monoisolates, and also studied haw the expressivity of R-genes was influenced by the temperature. The study was conducted in 2006-2010 using 28 collection flax specimens characterized by high resistance to $F$. oxysporum f. lini population. Also highly aggressive monoisolates and the most widespread races of the pathogen were used. To identify R-genes, the $F_{2}$ plants from crossing studied specimens with the lines possessing known R-genes were tasted with monoisolate № 39 Fusarium oxysporum f. lini. To rank the specimens on fusarium wilt resistance, the tests were conducted in the nurseries and a climatic chamber at optimal temperature $\left(26-28{ }^{\circ} \mathrm{C}\right)$, and the plant damage was estimated at early yellow ripeness or early development, respectively. A total of 16 specimens were shown to possess effective resistance genes. The other 12 specimens, when tested with different monoisolates, seemed not to be effectively resistant, moreover, their resistance decreased depending on an increased aggressiveness of some races of the pathogen due to weather conditions of the year. Hybridological analysis data were in line with phytopathological tests specifying genetic distinctions of specimens № 3896, 1. 6 (Russia); Siciliana 285, 1. 4 (Italy) and Honkej 21, 1. 4 (China) with effective resistance genes $F u 4, F u 7$ and $F u$, respectively. It was shown that at $26-28{ }^{\circ} \mathrm{C}$ during the seedlings-«herringbone» period an expressivity of resistance genes can decrease owing to increased aggressiveness of some races of the pathogen. At that, the effectiveness of $F u 7$ gene was significantly influenced by the raised temperatures, whereas the effect of R-genes in the k-5657 (Minnesota, the USA) did not depend on the temperature. The found sources possessing various Rgenes against fusarium wilt, when used in breeding, will help to avoid epiphytoty and to provide a sustainable flax production.
\end{abstract}

Keywords: fibre-flax, linseed, resistance, fusarial wilt, genetic sources, the temperature factor

Flax (Linum usitatissimum L.) species, due to high adaptiveness, are widely cultivated in Russia. These are fiber flax (Linum usitatissimum L. f. elongate) in northern and oilseed flax (Linum usitatissimum L. var. intermedia) in central and southern Russia [1].

Fusarium wilt caused by fungus Fusarium oxysporum f. lini, is one of the most harmful and widespread diseases in flax [2-4]. Many of today's domestic and foreign flax varieties are characterized by high and moderate resistance to the disease [5-7]. However, there is a risk to lose stability because of changes in the pathogen population, considerable genetic homogeneity of the varieties, improper crop rotation and the impact of climatic factors [8-10]. Fusarium wilt resistance in flax plants can be due to horizontal [11, 12] and vertical [13-15] resistance genes.

Since transmission of the infection occurs primarily through the soil and is slower than if the pathogen is transmitted by wind, water or insects, the single gene protection against Fusarium wilt is effective [16, 17]. Particularly, 
the variety A-1120, produced more than half a century ago, has been involved in breeding of most domestic flax varieties and ensures resistance to Fusarium wilt determined by two R-genes [18]. The advantage of the monogenic approach is a reduced time of breeding and a significant suppression of the disease.

The flax Fusarium wilt was first reported in the late XIX century, but to date only three wilt resistance genes have been identified in flax [19]. Dakota is a two-gene variety, and one gene is conferring resistance to wilt in Punjab variety but it is not effective against Russian Fusarium oxysporum f. lini population [20]. Moreover, the response of known flax R-genes to environmental changes has not been investigated. A limited set of genes conferring resistance to $F$. oxysporum $\mathrm{f}$. lini, and lack of information about reliable effect of these R-genes significantly impede the development of plants resistant to flax wilt in breeding programs.

In this work we have found the Fusarium wilt resistance genes effective in the Non-Chernozem zone of Russia in fiber and oilseed flax plants, and for the first time established a decrease in expression of some these genes at an air temperature above $25^{\circ} \mathrm{C}$.

The aim of the study was to identify different Fusarium wilt resistance genes in the global flax collection, and evaluate how the temperature influenced on their expression to ensure reliable and long-term protection of new varieties to the disease in the face of climate change.

Technique. A total of 28 fiber and oilseed flax (Linum usitatissimum L.) specimens high-resistant to $F$. oxysporum f. lini strains from different Russian regions [21] were tested phytopathologically in 2006-2010 with high-aggressive monoisolates and the most common pathogen races including isolates №№ 39, 187, 200 of the race 12, № 259 of the race 15, and №№ 282, 326, 293 and 284 [22].

To identify resistance genes, the $\mathrm{F}_{2}$ generations from crossing specimens with the lines having known R-genes were analyzed. The specimens from the All-Russian Flax Research Institute Collection were k-5240 (G-4729, 1. 3), k5588 (g-2101-4-7, 1. 7), k-4241 (Querandi, 1. 1), k-3978 (Currong, 1. 3), k-3510 (Roja, 1. 8), k-3218 (Dakota, 1. 8), k-1771 (Linota, 1. 12), k-5064 (Rodnik, 1. 2), and the lines 1. 303/8 $\mathrm{BC}_{2}(\mathrm{k}-5588, \mathrm{~g}-2101-4-7,1.7 \times \mathrm{k}-5324$, AP5 $)$ and 1. 252/7 $\mathrm{BC}_{2}$ (k-3510, Roja, 1. $8 \times \mathrm{k}-5323$, AP4) served as donors [23]. The monnoisolate № $39 \mathrm{~F}$. oxysporum f. lini was used as phytopathogen.

The pot tests under natural conditions and in a climatic chamber at controlled temperature $\left(26-28^{\circ} \mathrm{C}\right)$ were carried out according to recommendation [24].

The flax plant lesion index was calculated at early yellow ripeness using standard formula:

$$
\mathrm{Dd}=\frac{\Sigma(\mathrm{a} \times \mathrm{b}) \times 100}{\mathrm{~A} \times \mathrm{K}}
$$

with Dd as disease development, \%; a - the number of plants with the same Fusarium wilt lesion; $b-$ the lesion score; $\Sigma-$ the sum of the multiplied indexes; A - the recorded number of intact and affected plants; $\mathrm{K}-$ the highest score of the scale. The flax stem phytopathological damage was evaluated using 4-point scale, with 0 as the absence of lesions, unaffected plant; 1 as partial browning, unilateral stem browning; 2 as browning of the whole plant with capsules; 3 as completely brown dead plant, the plant lost before capsule formation.

The ranking of tested varieties and specimens for Fusarium wilt resistance was based on the percentage of affected plants, with $<20 \%$ for resistant (R), from 20 to $30 \%$ for low susceptible (LS), from 30 до $50 \%$ for moderately susceptible (MS), and $>50 \%$ for highly susceptible ones (S) [24].

Data were processed according to D.R. Metcalfe [25]. 
Results. Previously, we identified eight flax genes of $F$. oxysporum f. lini resistance, effective in Russia (Table 1).

1. Known genes of resistance to Fusarium wilt (Fusarium oxysporum f. lini) in flax (Linum usitatissimum L.) [26]

\begin{tabular}{|c|c|c|}
\hline Gene & Line & Author \\
\hline Fu 1 & Dakota, 1. 48-94 (k-3218, USA) & Knowles et al., 1955 \\
\hline \multirow[t]{2}{*}{ Fu 2} & Dakota, 1. 48-94 (k-3218, USA) & Knowles et al., 1955 \\
\hline & Dakota, 1.8 (k-3218, USA) & Rozhmina, 2000 \\
\hline Fи 3 & Punjab, 1. 53 (k-3217, India) & Knowles et al., 1956 \\
\hline \multirow[t]{4}{*}{ Fu 4} & G-4729, 1. 3 (k-5240, Russia) & Rozhmina, 1989 \\
\hline & № 340, 1.7 (k-4263, Argentina) & Rozhmina, 1994 \\
\hline & Areco, 1. 4 (k-5568, the Netherlands) & Rozhmina, 2005 \\
\hline & Atalante, 1. 2 (k-5575, the Netherlands) & Rozhmina, 2005 \\
\hline \multirow[t]{2}{*}{ Fu 5} & Querandi, 1. 1 (k-4241, Argentina) & Rozhmina, 1994 \\
\hline & K-65, 1.1 (к-6266, Belarus) & Rozhmina, 2012 \\
\hline Fи 6 & Currong, 1. 3 (k-3978, Australia) & Rozhmina, 1994 \\
\hline Fи 7 & Roja, 1. 8 (k-3510, Canada) & Rozhmina, 1994 \\
\hline \multirow[t]{3}{*}{ Fu 8} & g-2101-4-7 (k-5588, Russia) & Rozhmina, 1997 \\
\hline & Rodnik, 1.8 (k-5064, Belarus) & Rozhmina, 2000 \\
\hline & Z 95199 (k-6385, Romania) & Rozhmina, 2008 \\
\hline Fu 9 & Rodnik, 1. 8 (k-5064, Belarus) & Rozhmina, 2002 \\
\hline Fu 10 & Linota, 1. 12 (k-1771, Argentina) & Rozhmina, 2005 \\
\hline
\end{tabular}

A total of 16 specimens with high resistance to all eight $F$. oxysporum f. lini Russian monoisolates were found in the pot tests that indicated the presence of R-genes to local pathogenic races, whereas the rest 12 specimens were not enough effective (Table 2). At that, some races became more aggressive depending on weather conditions. These were mononisolate № 282 in 2006 and monoisolates №№ 259 of the race 15 in 2008. In 2006, almost all of 12 specimens, except k-6217, were affected by one or more monoisolates.

2. Response of flax (Linum usitatissimum L.) specimens to Fusarium oxysporum f. lini monoisolates (pot tests, All-Russian Flax Research Institute, Tver' Province)

\begin{tabular}{|c|c|c|c|c|c|c|c|c|c|}
\hline \multirow{2}{*}{$\begin{array}{l}\text { ARFRI Collection number, specimen } \\
\text { name and origin }\end{array}$} & \multirow{2}{*}{ Year } & \multicolumn{8}{|c|}{ Monoisolate number } \\
\hline & & 39 & 187 & 200 & 259 & 282 & 326 & 293 & 284 \\
\hline \multirow[t]{2}{*}{ k-5645, Linda, France } & 2006 & I & SM & I & I & I & $\mathrm{R}$ & I & $\mathrm{y}$ \\
\hline & 2008 & $\mathrm{R}$ & I & - & S & LS & SM & - & - \\
\hline \multirow[t]{2}{*}{ k-5047, Buenos Aires, Argentina } & 2006 & $\mathrm{R}$ & $\mathrm{R}$ & I & $\mathrm{R}$ & SM & $\mathrm{R}$ & I & SM \\
\hline & 2008 & SM & LS & - & SM & LS & SM & - & - \\
\hline \multirow[t]{2}{*}{ k-5656, Michail, France } & 2006 & SM & $\mathrm{R}$ & I & $\mathrm{R}$ & SM & LS & I & I \\
\hline & 2008 & $\mathrm{R}$ & I & - & SM & $\mathrm{R}$ & SM & - & - \\
\hline \multirow[t]{2}{*}{ k-5317, g-1847-4-1, Russia } & 2006 & SM & SM & $\mathrm{R}$ & $\mathrm{R}$ & SM & LS & I & $\mathrm{R}$ \\
\hline & 2008 & SM & SM & - & SM & S & SM & - & - \\
\hline \multirow[t]{2}{*}{ k-4830, № 363-4, France } & 2006 & И & S & I & LS & SM & SM & I & $\mathrm{R}$ \\
\hline & 2008 & $\mathrm{R}$ & I & - & - & $\mathrm{R}$ & I & - & - \\
\hline \multirow[t]{2}{*}{ k-4626, D-1444-66, Belarus } & 2006 & $\mathrm{~S}$ & LS & $\mathrm{R}$ & $\mathrm{R}$ & $\mathrm{S}$ & SM & I & LS \\
\hline & 2008 & I & I & - & I & $\mathrm{R}$ & $\mathrm{R}$ & - & - \\
\hline \multirow[t]{2}{*}{ k-4830, C-108, Russia } & 2006 & $\mathrm{~S}$ & S & $\mathrm{R}$ & $\mathrm{R}$ & S & $\mathrm{S}$ & $\mathrm{R}$ & SM \\
\hline & 2008 & SM & SM & - & LS & SM & S & - & - \\
\hline \multirow[t]{2}{*}{ k-4613, Fakel, Russia } & 2006 & SM & S & LS & S & S & $\mathrm{S}$ & I & $\mathrm{S}$ \\
\hline & 2008 & I & I & - & I & $\mathrm{R}$ & $\mathrm{R}$ & - & - \\
\hline \multirow[t]{2}{*}{ k-5246, 1. 07-107, Russia } & 2006 & $\mathrm{~S}$ & $\mathrm{~S}$ & I & LS & $\mathrm{S}$ & $\mathrm{S}$ & $\mathrm{R}$ & I \\
\hline & 2008 & SM & SM & - & SM & SM & $\mathrm{R}$ & - & - \\
\hline \multirow[t]{2}{*}{ k-317, L-1120, Russia } & 2006 & S & S & I & I & S & $\mathrm{S}$ & SM & SM \\
\hline & 2008 & LS & $\mathrm{S}$ & - & SM & $\mathrm{R}$ & LS & - & - \\
\hline \multirow[t]{2}{*}{ k-6264, Artemida, Poland } & 2006 & LS & S & I & $\mathrm{R}$ & SM & $\mathrm{R}$ & I & LS \\
\hline & 2008 & $\mathrm{~S}$ & SM & - & SM & SM & S & - & - \\
\hline \multirow[t]{2}{*}{ k-6217, V-874410, China } & 2006 & I & I & I & I & $\mathrm{R}$ & I & I & LS \\
\hline & 2008 & LS & $\mathrm{S}$ & - & $\mathrm{S}$ & SM & $\mathrm{S}$ & - & - \\
\hline Standard Slavnii 82 & & $\mathrm{~S}$ & $\mathrm{~S}$ & $\mathrm{~S}$ & $\mathrm{~S}$ & $\mathrm{~S}$ & $\mathrm{~S}$ & $\mathrm{~S}$ & $\mathrm{~S}$ \\
\hline
\end{tabular}

N o t e. ARFRI - All-Russian Flax Research Institute. The specimens were ranked for Fusarium wilt resistance based on the percentage of affected plants - from 1 to $20 \%$ for R, from 21 to $30 \%$ for LS, from 31 до $50 \%$ for MS, and more than $50 \%$ for S; I means immunity. Dashes mean no data obtained.

The data allows to conclude the genetic diversity for wilt resistance among tested flax specimens, and genetic differences between $F$. oxysporum f. lini 
monoisolates themselves.

The 16 specimens high resistant in pot tests under natural conditions were further tested in a climatic chamber at $26-28{ }^{\circ} \mathrm{C}$ optimal for $F$. oxysporum f. lini when plant death occurred in early ontogeny. The findings indicated the monoisolates №№ 187, 282 and 326 aggressiveness increased at an elevated air temperature during seedlings to «herringbone» stage (Table 3).

3. Response of fiber and oil flax (Linum usitatissimum L.) specimens resistant to Fusarium wilt to different Fusarium oxysporum f. lini monoisolates in a climatic chamber at $26-28{ }^{\circ} \mathrm{C}$ (during seedlings to «herringbone» stage)

\begin{tabular}{|c|c|c|c|c|c|c|}
\hline \multirow{2}{*}{$\begin{array}{l}\text { ARFRI Collection number, specimen } \\
\text { name and origin }\end{array}$} & \multirow{2}{*}{ Botanic form } & \multicolumn{5}{|c|}{ Monoisolae number } \\
\hline & & 39 & 187 & 259 & 282 & 326 \\
\hline k-5657, Minnesota, USA & Intermediate flax & $\mathrm{R}$ & I & I & I & RS \\
\hline k-1709, Redwing Sel., USA & Intermediate flax & $\mathrm{R}$ & I & RS & $\mathrm{R}$ & SR \\
\hline k-5245, 1. k-6746, Russia & Fiber flax & $\mathrm{R}$ & SR & I & SR & $\mathrm{R}$ \\
\hline k-6333, Sweden & Intermediate flax & SR & SR & $\mathrm{R}$ & SR & RS \\
\hline k-5383, Honkei 21, China & Fiber flax & RS & $\mathrm{S}$ & I & RS & $\mathrm{R}$ \\
\hline k-5635, № 3896, Russia & Intermediate flax & RS & RS & $\mathrm{R}$ & $\mathrm{S}$ & RS \\
\hline k-6268, Signal, Belarus & Fiber flax & RS & $\mathrm{R}$ & $\mathrm{R}$ & $\mathrm{S}$ & $\mathrm{R}$ \\
\hline k-5404, Honkei 41, China & Fiber flax & $\mathrm{R}$ & $\mathrm{R}$ & $\mathrm{R}$ & $\mathrm{S}$ & RS \\
\hline k-4972, 4025/15, Ukraine & Fiber flax & I & $\mathrm{R}$ & $\mathrm{R}$ & $\mathrm{S}$ & RS \\
\hline k-5327, KLN, Russia & Fiber flax & $\mathrm{R}$ & SR & RS & $\mathrm{S}$ & SR \\
\hline k-5365, Honkei 334, China & Fiber flax & RS & SR & I & $\mathrm{S}$ & SR \\
\hline k-5396, Honkei 35, China & Fiber flax & $\mathrm{R}$ & SR & I & $\mathrm{S}$ & SR \\
\hline k-5413, Minamishi, Japan & Fiber flax & SR & SR & $\mathrm{R}$ & S & SR \\
\hline k-4056, Siciliana 285, Italy & Large-seeded flax & RS & $\mathrm{S}$ & I & $\mathrm{S}$ & SR \\
\hline k-6339, Fr-681, Canada & Intermediate flax & RS & SR & I & SR & $\mathrm{S}$ \\
\hline k-6215, № 8714/2, China & Fiber flax & SR & SR & I & SR & S \\
\hline $\begin{array}{l}\text { N o t e. ARFRI - All-Russian Flax Resear } \\
\text { wilt resistance based on the percentage of a } \\
31 \text { до } 50 \% \text { for MS, and more than } 50 \% \text { fo } \\
20 \% \text {, УВ LS - от } 21 \text { до } 30 \% \text {, MS ВУ - }\end{array}$ & I means immunity & сте & b по & re $\mathrm{r}$ & $f$ & $\begin{array}{l}\text { arium } \\
\text { from } \\
\text { г } 1 \text { до }\end{array}$ \\
\hline
\end{tabular}

In the climatic chamber at controlled temperature $\left(26-28{ }^{\circ} \mathrm{C}\right)$ the $\mathrm{k}-5657$ specimen (Minnesota) was highly resistant to all tested monoisolates; k-5383 (Honkei 21) was highly susceptible to monoisolate № 187 with $>50 \%$ of the plants damaged; k-5635 (№ 3896), k-5327 (KLN), k-6268 (Signal), k-4972 (4025/15), k-5404 (Honkei 41), k-5365 (Honkei 334), k-5396 (Honkei 35) and k-5413 (Minamishi) were susceptible to № 282 monoisolate; k-6339 (Fr-681) and k-6215 (№ 8714/2) were susceptible to monoisolate № 326; k-4056 (Siciliana 285) was susceptible to monotolates №№ 187 and 282.

It seems reasonable to assume that the resistance of these specimens to Fusarium wilt is controlled by different R-genes which expression is influenced by temperature, in one way or another, due to changes in aggressiveness of some races of the pathogen. The specimens of the same group and susceptible to the same monoisolate but resistant to another monoisolates were genetically close.

Analysis of $\mathrm{F}_{2}$ generation in crossing lines which possess different $\mathrm{R}$ genes with the specimens k-4056 (Siciliana-285, 1. 3, Italy), k-5635 (№ 3896, 1. 6, Krasnodar Krai) and k-5383 (Honkej 21, 1. 4, Japan) revealed mostly digenic segregation character ( $\chi^{2}$ from 0 to 3.75 ) (Table 4 ). Consequently, the resistance of the tested specimens is determined by one effective gene different from the Rgenes of the lines, used in the hybridization. The exception was a hybrid combination with the variety Rodnik (the proportion of resistant to susceptible plants is 63 to 1), because its resistance was controlled by two dominant genes.

In the populations $\mathrm{F}_{2}$ 1. 252/7 $\mathrm{BC}_{2}(\mathrm{k}-3510$, Roja, $1.8 \times \mathrm{k}-5323$, AP4) $\times$ k-4056, Siciliana 285, 1. 3; F 2 k-5240, G-4729, 1. $3 \times$ k-5635, № 3896, 1. 6; $\mathrm{F}_{2}$ 1. 303/8 BC $2(\mathrm{k}-5588, \mathrm{~g}-2101-4-7,1.7 \times \mathrm{k}-5324$, AP5 $) \times \mathrm{k}-5383$, Honkej 21, 1. 4 no segregation was observed indicating identity of the resistance genes in the parents involved in a hybrid combination.

Hybridological analysis confirmed the phytopathological test results, in- 
dicating the genetic differences among the specimens for disease resistance. This trait was determined by $F u 7$ gene in Siciliana 285, 1. 3; Fu 8 gene in Honkej 21, 1. 4; and $F u 4$ gene in № 3896, 1. 6. High resistance to the pathogen in these specimens under the conditions of the Non-Chernozem zone of Russia testifies to the effectiveness of the identified R-genes.

4. Segregation for resistance to Fusarium oxysporum f. lini monoisolate № 39 in $\mathbf{F}_{2}$ from crossing resistant flax (Linum usitatissimum L.) lines (All-Russian Flax Research Institute, Tver' Province, 2008-2010)

\begin{tabular}{|c|c|c|c|c|c|}
\hline \multirow{2}{*}{ Crossing } & \multirow{2}{*}{ Gene $F u$} & \multicolumn{2}{|c|}{$\mathrm{R}$ to $\mathrm{S}$ phenotype proportion } & \multirow{2}{*}{$\chi^{2}$} & \multirow{2}{*}{$\mathrm{P}$} \\
\hline & & obtained & expected & & \\
\hline k-3218 (Dakota, 1. 8) × k-5383 (Honkei 21, 1. 4) & 2 & 139:11 & $15: 1$ & 0.29 & $0.8-0.5$ \\
\hline $\mathrm{k}-5240(\mathrm{G}-4729,1.3) \times \mathrm{k}-5383($ Honkei $21,1.4)$ & 4 & $131: 4$ & $15: 1$ & 2.46 & $0.2-0.05$ \\
\hline k-4241 (Querandi, 1. 1) × k-5383 (Honkei 21, 1. 4) & 5 & $226: 12$ & $15: 1$ & 0.57 & $0.5-0.2$ \\
\hline k-3978 (Currong. 1. 3) × k-5383 (Honkei 21, 1. 4) & 6 & 101:4 & $15: 1$ & 1.09 & $0.5-0.2$ \\
\hline k-3510 (Roja, 1. 8) × k-5383 (Honkei 21, 1. 4) & 7 & $74: 5$ & $15: 1$ & 0 & $<0.99$ \\
\hline $\begin{array}{l}\text { 1. } 303 / 8 \mathrm{BC}_{2}(\mathrm{k}-5588, \mathrm{~g}-2101-4-7,1.7 \times \mathrm{k}-5324 \text {, } \\
\text { AP5) } \times \mathrm{k}-5383 \text { (Honkei } 21,1.4)\end{array}$ & 8 & $120: 0$ & & & \\
\hline k-1771 (Linota, 1. 12) × k-5383 (Honkei $21,1.4)$ & 10 & $110: 4$ & $15: 1$ & 1.44 & $0.5-0.2$ \\
\hline k-3218 (Dakota, 1. 8) × k-4056 (Siciliana $285,1.3)$ & 2 & $185: 19$ & $15: 1$ & 3.20 & $0.2-0.05$ \\
\hline $\mathrm{k}-5240(\mathrm{G}-4729,1.3) \times \mathrm{k}-4056($ Siciliana $285,1.3)$ & 4 & $153: 7$ & $15: 1$ & 0.96 & $0.5-0.2$ \\
\hline k-4241 (Querandi, 1. 1) × k-4056 (Siciliana 285, 1. 3) & 5 & $163: 6$ & $15: 1$ & 2.13 & $0.2-0.05$ \\
\hline k-3978 (Currong, 1. 3) × k-4056 (Siciliana 285, 1. 3) & 6 & $192: 20$ & $15: 1$ & 3.61 & $0.2-0.05$ \\
\hline & & $149 \cdot 0$ & & & \\
\hline k-5064 (Rodnik, 1. 8) × k-4056 (Siciliana $285,1.3)$ & 9 & $\begin{array}{l}149: 0 \\
101: 2\end{array}$ & $63: 1$ & 0.1 & $0.8-0.5$ \\
\hline k-1771 (Linota, 1. 12) $\times$ k-4056 (Siciliana $285,1.3)$ & 10 & $147: 11$ & $15: 1$ & 0.12 & $0.8-0.5$ \\
\hline k-3218 (Dakota, 1. 8) × k-5635 (№ 3896, 1. 6) & 2 & 208:13 & $15: 1$ & 0.05 & $0.95-0.8$ \\
\hline k-5240 (G-4729, 1. 3) × k-5635 (№ 3896, 1. 6) & 4 & 92:0 & - & - & - \\
\hline k-4241 (Querandi, 1. 1) × k-5635 (№ 3896, 1. 6) & 5 & $232: 10$ & $15: 1$ & 1.80 & $0.2-0.05$ \\
\hline k-3978 (Currong, 1. 3) × k-5635 (№ 3896, 1. 6) & 6 & $107: 7$ & $15: 1$ & 0 & $<0.99$ \\
\hline k-3510 (Roja, 1. 8) × k-5635 (№ 3896, 1. 6) & 7 & 183:7 & $15: 1$ & 2.16 & $0.8-0.5$ \\
\hline $\mathrm{k}-5588(\mathrm{~g}-2101-4-7,1.7) \times \mathrm{k}-5635$ (№ 3896, 1. 6) & 8 & 141:6 & $15: 1$ & 1.19 & $0.5-0.2$ \\
\hline k-1771 (Linota, 1. 12) × k-5635 (№ 3896, 1. 6) & 10 & $97: 3$ & $15: 1$ & 3.75 & $0.2-0.05$ \\
\hline
\end{tabular}

The differences in plant resistance identified phytopathologically can be due to the fact that the identified genes in flax pre-constitute closely-linked units, which provide the effect of a monogenic control [26]. However, some genes of these oligogenes may be influenced by the temperature leading to a decrease in expression like in the $F u 7$ gene.

Thus, the genes effectively conferring Fusarium wilt resistance in NonChernozem zone of Russia have been identified in 16 specimens of the world fiber and oil flax collection using the phytopathological test. An increased aggressiveness of some races of the pathogen and a decreased expression of some plant R-genes at air temperature above $25^{\circ} \mathrm{C}$ have been found. Gene $F u 7$ which controls Fusarium wilt resistance in the line Siciliana 285 was mostly temperatureinfluenced as at $26-28{ }^{\circ} \mathrm{C}$ the line became susceptible to monoisolates № 187 and № 282, and moderately resistant to monoisolate № 326. In k-5657, Minnesota (USA) expression of R-genes to Fusarium oxysporum f. lini was temperature-independent. So new sources of the effective R-genes against Fusarium wilt in flax are Siciliana 285, line 3 (Italy) with $F u$ 7, Honkej 21, line 4 (China) with $F u$ 8, and № 3896, line 6 (Russia) with $F u$ 4. Their involvement in fiber and oil flax breeding programs will contribute to preventing Fusartium wilt epiphytotics in flax.

\section{R E F E R E N C E S}

1. Zhuchenko A.A., Rozhmina T.A., Ponazhev V.P., Pavlova L.N., Tikhomi rova V.Ya., S o r o k i n O.Yu. Ekologo-geneticheskie osnovy selektsii l'na-dolguntsa [Ecogenetic base for flax breeding]. Tver', 2009 (in Russ.).

2. Kroes I., Rashid K., Trouve J.-P., Dombry G., Ham mond J., Wull mers E., 
Roz h mi na T., K e is e r P., La ng e W. Assessment of resistance to Fusarium oxysporum $\mathrm{f}$. sp. lini in flax and linseed across locations and years. Aspects of resistance of flax and linseed (Linum usitatissimum) Fusarium oxysporum f. sp. L. Wageningen, 1997: 105-137.

3. K roes G.M.L.W., Lö f fle r H.J.M., P a rle v li e t J.E., K e i z e r L.C.P., La nge W., Interactions of Fusarium oxysporum f. sp. lini, the flax wilt pathogen, with flax and linseed. Plant Pathol., 1999, 48: 491-498.

4. R a s hid K. Principal diseases of flax. In: Flax. The genus Linum. London-NY, 2003: 74-92.

5. Diederichsen A., Rozhmina T., Kudrjavceva L., Zhuchenko A., Jr. Variation patterns within 153 flax (Linum usitatissimum L.) genebank accessions based on evaluation for resistance to fusarium wilt, anthracnose and pasmo. Plant Genetic Resources: Characterization and Utilization, 2008, 6(1): 22-32.

6. Ku mar M., Tripathi U.K., Tomer A., Ku mar P., S ingh A. Screening of linseed germplasm for resistance. Tolerance against Fusarium oxysporum f. sp. lini (Bolley) disease. Plant Pathol. Microbiol., 2014, 5: 235 (doi: 10.4172/2157-7471.1000235).

7. M p of u S.I., R a s h i d K.Y. Vegetative compatibility groups within Fusarium oxysporum f. sp. lini from Linum usitatissimum (flax) wilt nurseries in western Canada. Journal of Botany, 2011, 79(7): 836-843.

8. Gruzdevienè E., Brazauskienè I., Repečkienè J., Lugauskas A. The occurrence of pathogenic fungi during flax growing season in central Lithuania. Journal of Plant Protection Research, 2008, 48(2): 255-264.

9. Li n $\mathrm{Yu}$ an, $\mathrm{Na} \mathrm{Mi,} \mathrm{Shanshan} \mathrm{Liu,} \mathrm{Hui} \mathrm{Ziqin} \mathrm{Li.} \mathrm{Genetic} \mathrm{diversity} \mathrm{and} \mathrm{structure}$ of the Fusarium oxysporum f. sp. lini populations on linseed (Linum usitatissimum) in China. Phytoparasitica, 2013, 41: 391-401 (doi: 10.1007/s12600-013-0300-6).

10. Shindi n A.P., Z a k harova L.M., P avlova L.N., R o z h mina T.A. Len. Tekhnologii vozdelyvaniya $i$ zashchity ot vrednykh organizmov [Flax: agro technologies and pest protection]. Moscow, 2012 (in Russ.).

11. D y n n i k V.P., Evm i nov V.N. Len i konoplya, 1982, 5: 33-34 (in Russ.).

12. P a vele k M. Dedicnost horisontalni resistance pradneho lnu proti fusarioze. Len a konopi (Czech Republic), 1983, 19: 7-164.

13. Spielmeyer W., Lagudah E.S., Mendham N., Green A.G. Inheritance of resistance to flax wilt (Fusarium oxysporum f. sp. lini) in a doubled haploid population of Linum usitatissimum L. Euphytica, 1998, 101: 287-291 (doi: 10.1023/A:1018353011562).

14. Roz h min a T.A. V sbornike: Geneticheskie osnovy selektsii [In: The genetic basis of breeding]. Ufa, 2008: 233-247 (in Russ.).

15. Kumar N., Paul S., Kumar A., J a mwal N.S. Inheritance of gene conferring resistance to wilt (Fusarium oxysporum f. sp. lini) disease of linseed (Linum usitatissimum L.) in North West Himalayas. Electronic Journal of Plant Breeding, 2015, 6(4): 1108-1110.

16. Ha 11 L.M., B o o k e r H., S i lot o R.M.P., J hal a A.J., W e s e la k e R.J. Flax (Linum usitatissimum L.). In: Industrial oil crops. T. McKeon, D. Hayes, D. Hildebrand, R. Weselake (eds.). AOCS Press, Elsevier Inc., 2016: 157-194 (doi: 10.1016/B978-1-893997-98-1.00006-3).

17. $\mathrm{R} \mathrm{ozh} \mathrm{mina} \mathrm{T.A.} \mathrm{V} \mathrm{sbornike:} \mathrm{Identifitsirovannyi} \mathrm{genofond} \mathrm{rastenii} \mathrm{i} \mathrm{selektsiya} \mathrm{[In:} \mathrm{The} \mathrm{identi-}$ fied plant gene pool and breeding]. St. Petersburg, 2005: 406-419 (in Russ.).

18. Rozhmina T.A. Geneticheskoe raznoobrazie l'na (Linum usitatissimum) i ego kompleksnoe ispol'zovanie v selektsii. Avtoreferaat doktorskoi dissertatsii [Genetic diversity in flax (Linum usitatissimum) as used in breeding. DSci Thesis]. St. Petersburg, 2004 (in Russ.).

19. Kutu z ova S.N. V sbornike: Genetika kul'turnykh rastenii [In: Genetics of cultivated plants]. St. Petersburg, 1998: 6-52 (in Russ.).

20. Golubev A.E., Rozhmina T.A., Ponazhev V.P., Ryzhov A.I., Ryzhov I.A., Se min M.I. Selektsionno-geneticheskie osnovy syr'evogo obespecheniya l'novodstva [Genetic basis and breeding to provide primary products in flax cultivation]. Moscow, 2010 (in Russ.).

21. Los hakova N.I., Kud ryavts eva L.P., P av lova L.N., Roz h m i na T.A. Maslichnye kul'tury (nauchno-tekhnicheskii byul. VNIIMK, Krasnodar), 2014, 2(159-160): 172-178 (in Russ.).

22. L o s h a k o v N.I. V sbornike: Selektsiya, semenovodstvo, agrotekhnika, ekonomika i pervichnaya obrabotka l'na-dolguntsa [In: Flax: breeding, seed production, cultivation, economy, and rough processing]. Torzhok, 2002: 44-47 (in Russ.).

23. Zhuchenko T.A., Rozhmina T.A. Mobilizatsiya geneticheskikh resursov l'na [Mobilization of flax genetic resources]. Staritsa, 2000 (in Russ.).

24. Loshakova N.I., Krylova T.V., Kudryavtseva L.P. Metodicheskie ukazaniya po fitopatologicheskoi otsenki ustoichivosti l'na-dolguntsa $k$ boleznyam [Phytopathological evaluation of flax resistance to diseases: guidelines]. Torzhok, 2000 (in Russ.).

25. Metcalfe D.R., H e lga s o n S.B. Inheritance of loose smut resistance. Canad. J. Plant Sci., 1962, 42(3): 472-480.

26. Ro z h mi n a T.A. Dostizheniya nauki i tekhniki APK, 2015, 12: 47-49 (in Russ.). 